\title{
Electricity as Applied to Torpedo and Other Naval Purposes
}

\section{Lieutenant F. T. Hamilton R.N.}

To cite this article: Lieutenant F. T. Hamilton R.N. (1892) Electricity as Applied to Torpedo and Other Naval Purposes, Royal United Services Institution. Journal, 36:172, 617-634, DOI: 10.1080/03071849209417655

To link to this article: http://dx.doi.org/10.1080/03071849209417655

\section{曲 Published online: 11 Sep 2009.}

Submit your article to this journal

Џll Article views: 9

Q View related articles $匚$ 
Wednesday, May 4, 1892.

Adsirat H.R.H. THE DUKE OF EDINBURGH, K.G., K.T., G.C.B., ic., \&c., A.D.C., Commander-in.Chief, Devouport, in the Chair.

\section{FLECTRICITY $A S$ APPLIED TO TORPEDO AND OTHER NAVAL PURPOSES.}

\section{By Lieutenant F. 'I. HAMILTOx, R.N.}

Ix May, 1885, a lecture on this subject was given at this Institution by Licutenant, now Commander, Batten, when Sir Cooper Key took the chair. Since that tinie, although we lave not learnt very muck that is actually new about electricity, great adrances have been made in perfecting the methods of application, and, as a necessary consequence of competition amon: manufacturers, the material used becomes better and elheaper every day; therefore its use for naval purposes has becomo more extended. At one time there was a great tendency to elaborate most intricate machines, which were expected to do ererything short of talking, but the more practical experience we get the more we see that electricity, for naral purposes, must be applied in such a manner that the instruments and machines usca must be simple, and made in such a way that they will stand the exposure and rough usage inseparable from ship work.

In dealing with this subject, there is not time in the limits of a short lecture to go into the whole question, or to go over again any of the ground trodden by Commander Batten, nor, indeed, is it necessary; therefore it is proposed now merely to make a sketch of the principal points on which wo hare mado advauices since 1885. And to facilitate comparison, I will take the different branches of the subject as near as possible in the same order as in the 1885 lecture.

\section{Electric Lighting.}

Taking, then, electric lighting first. The internal lighting of menof-war has now become the rulo instead of the exception; it is found that it is economical, clean, and convenient, and, cxcept in the case of quite small vessels, where space does not admit of duplicating the dynamos, and the complement does not admit of telling of special - men to tend the machinery, it is invariably fitted. $A$ trial was made at one time of using the hull of the ship as a return, and the "Polyphemus," the P. and O. steamer "Mnssilia,": and Brazilian 
ironclad "Riachuelo," and other ressels, wero so fitted. The adrantage of sach a manner of fitting is only economy; the disadrantage is an increased risk of an accidental brcakdopin, for this reason: If you hare a complete wire system, a leak on one lead does no harm, and a second leak on the same lead does no harm; it is only when a leak occurs on both leads that harm is done, whereas with the carth return system a single leak at once disables a part of the circuit, thus donbling the chances of a breakdown. The complete wire system is, therefore, always used now, an alternative system of candle lighting being always fitted as well in English men-of-war, the reason being, not so much to provide against breakdowns, as with the amount of dynamo machivery now supplied that is an unlikely occurrence, but to provide against the contingency of not being able to light your fires, or of wanting to economize coal. This latter point, viz., economy of coal, is a very inportant one. In war-time a cruizer will probably require erery pound of coal she can carry for steaming purposes, and she will probably use no electric light at all. To give an idea of what this incans, practically, a ressel of the "Latona" clnss would use about 5 tons of coal for kceping her internal lighting going for a week, and the space occupied by this amount of coal would stow candles sufficient to last the ship for nearly six months. I do not mention this as a reason for not lighting ships internally, but rather to show the necessity, in war-time especially, of haring the alternative ssstem of candle lighting; or, in other words, as a geveral rule, clectric lighting is a great economy and conreuience, and, as such, we are ritght in employing it; but occasions may arise, especially in war, when the small amount of coal it uses cannot be spared, when no money could represent to us the value of a few extra tons of facl.

With regard to the fittings for internal ligiting, no great change Las taken place, bat all the sinaller changes are worbing in the diree. tion of making everything as watertight as possible, and the cables instead of beiug led about the ship in more or less clumsy wooden casings, are now made corered in lead, and are put up without any casing, the lead being considered to be ample protection.

With regard to the search light, its uso has largely developed, many more being now carried; there is, howerer, still a great differ: ence of opinion as to the best way of using it. Some prefer a large number of small lights (one war ressel haring as nany as 13), others prefer a smaller uumber of lights of high candle power; of course the more powerful light penetrates farthest, but it is open to the same objection as the market basket that contains all the eggs. On the other hand, a large number of lights must be confusing to those using them, and tend to make the ship vers conspicuons. Another point connected with the search light that gives rise to great controrersy is, whether it should be high or low; if high, the surface of water that is covered by the concentrated beam is very small, and consequently there is a difficnlty in picking ap an object; if low, some say that the rays striking the water are refected upwards, aud striking on the mist form a screen to objects beyoud. 'l'here is one point on 
which every one is apparently agroed, that the farther you go from the source of the search light, the better you sce the objects it illuminates; for this reason, the smallest ganbosts are given a powerful electrical apparatus, as they are alwajs likely to be useful as electric light stations for the larger ships. Vessels are also sometimes supplied witl portable search light plant, so that it can bo landed at a suitable point commanding the anchorage, and well away from the ship herself.' Another meaus by which the observer is enabled to get away from the scarch light is by using the antomatic lamp and controllable projector: By means of an electric motor in the pedestal of the projector, it can be directed both in elevation and training, by mercly pressing electric buttons at a distance. There are numerons automatic lamps, that is, lamps in which the consuming carbons are mado to feed themselves by atilizing the magnetic force of the same current that canses the light, but unless we have a projector controlled in the manner. I have just stated, the antomatic lamp is not worth the extra complication it involres, as, if we are obliged to hare a man at the projector to train it and elerate it, wo may as well let him regulate the carbons by land. The objection to the controllable projector is its weight and complication. But still the fact that it enables the same person that is observing the approaching torpedo-boat to direct tho movements of the projector himself, instead of passing orders to another man (always an uncertain proceeding), perhaps outweighs the objections.

\section{Seconlary Batteries.}

Having considered tho adrance made in electric lighting, let us now consider secondary batteries or accumulators, by which we are cnabled to store up electricity, and uso it again when we require it, the operation of storing only depriving us of about 10 per cent. of the carrent. Theso batteries are very convenient for barning clectric light, driving electric boats, and for any other purpose for which a powerful and constant current is required. The objections to their use are their weight (as the plates composing them are made of lead), the time they take to clarge, and the fact that they require most carcful handling, and are ensily injured if neglected, or charged or discharged too quickly. The aim of all the manufacturers has been, of course, to diminish these objections as much as possible, but, so far, not with rery marked success. To illustrate one of their uses, I have got here a battery of forty of these secondary cells, kindly lent by the Electric Power and Stornge Company, for giving us carrent to work these lights and instruments, and it will be a good example of the direction in which the inakers are working if $I$ show you how they have improred their cells. One of tho great difficulties has been that if the cells are charged or discharged too rapidly, the positivo plates bond and touch the negative plates, and so short-circuit the cell (as it is termed) and spoil it. Tho plates of the cells are made of lead, rith a paste of oxide of lead adhering to the surface. In the carlicr plates the lead is formed iuto a grid, and the oxido 
placed in the holes; these lumps of oxide zonstantly drop out when the plates bend.: In the latest form of plate there is more lead, so it is less liable to bend, and the oxide seems to stick in better. This gain in strength enables the cell to be charged and discharged at twice the rate' of the earlicr pattern, but as there is less oxide comparcd to the size of the plate, there is less capacity; that is, the cell will not store so much electricity, and slso it is heavicr in proportion to the work it does: The following table will give an idea of the advance made in the rate of charging and discharging, and the expenso in weight' and capncity at which it is gained :-

\begin{tabular}{|c|c|c|c|c|c|}
\hline Tspe. & $\begin{array}{c}\text { Size. of } \\
\text { plate }\end{array}$ & $\begin{array}{l}\text { Mraximum } \\
\text { rate of } \\
\text { diecharge. }\end{array}$ & $\begin{array}{c}\text { Time } \\
\text { of } \\
\text { discharge. }\end{array}$ & Capacits. & $\begin{array}{l}\text { Weight of } \\
31 \text {-plate cell } \\
\text { complete. }\end{array}$ \\
\hline $\boldsymbol{I}_{\mathbf{K}}(\mathbf{\text { old }}) \ldots \ldots$ & $\begin{array}{l}9 \text { gq. in. } \\
9 \text { gq. in. }\end{array}$ & $\begin{array}{c}\text { amperes } \\
4 \\
8\end{array}$ & $\begin{array}{l}\text { hours } \\
9 \\
3_{2}^{1}\end{array}$ & $\begin{array}{c}\text { smpire hours } \\
36 \\
28\end{array}$ & $\begin{array}{l}\text { lbs. } \\
\mathbf{2 8 6} \\
\mathbf{3 5 7}\end{array}$ \\
\hline
\end{tabular}

-It is not ndvisable that thie rate of charging should be more than 75 per cent. of that of discharging.

The improvements have therefore given us a stronger and less delicate cell, and one that can be charged and discharged at double the former rate without injury, bat we get this at a cost of about 22 per cent. less capacits, and 33 per cent. more weight. Tho deterioration is now calculated at about: $7 \frac{1}{2}$ to 15 . per cent. per annum. A light and efficient accumulator is a boon we must look forward to yet; with it, steam launches wonld soon become a thing of the past, and we should bo within a measurable distanco of tho flying machine. Besides the cells I have been describing, a small form is also used for taking the place of primary cells in cases where power is necessary and space is an object, such as in the case of small hand lamps; in the small form, liowever, tho secondary cell is an expensire laxury, as it is even moro delicate than the largo one, and therefore its life is generally not long.

Whilst on the subject of cells and batteries, I will point ont a late development of the primary battery which bids fair to come largely into ase, that is, the so-called dry cell. In this tho liquid is absorbed by plaster of Paris, or gelatine, or some doughy substance, so that there is nothing to upset. Hellescn's cells, which are an example of this type, were nsed in the small electric boat on the lake at the Naral Fxhibition, for working a small magnet in the vuat; the remained in use the whole time the Exhibition was open, which proves that tbey haro great lasting power. They are excellent for ringing bells nnd such like work, and promise well even for batteries, for firing detonators and charges, under some circumstances.

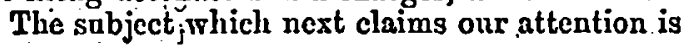




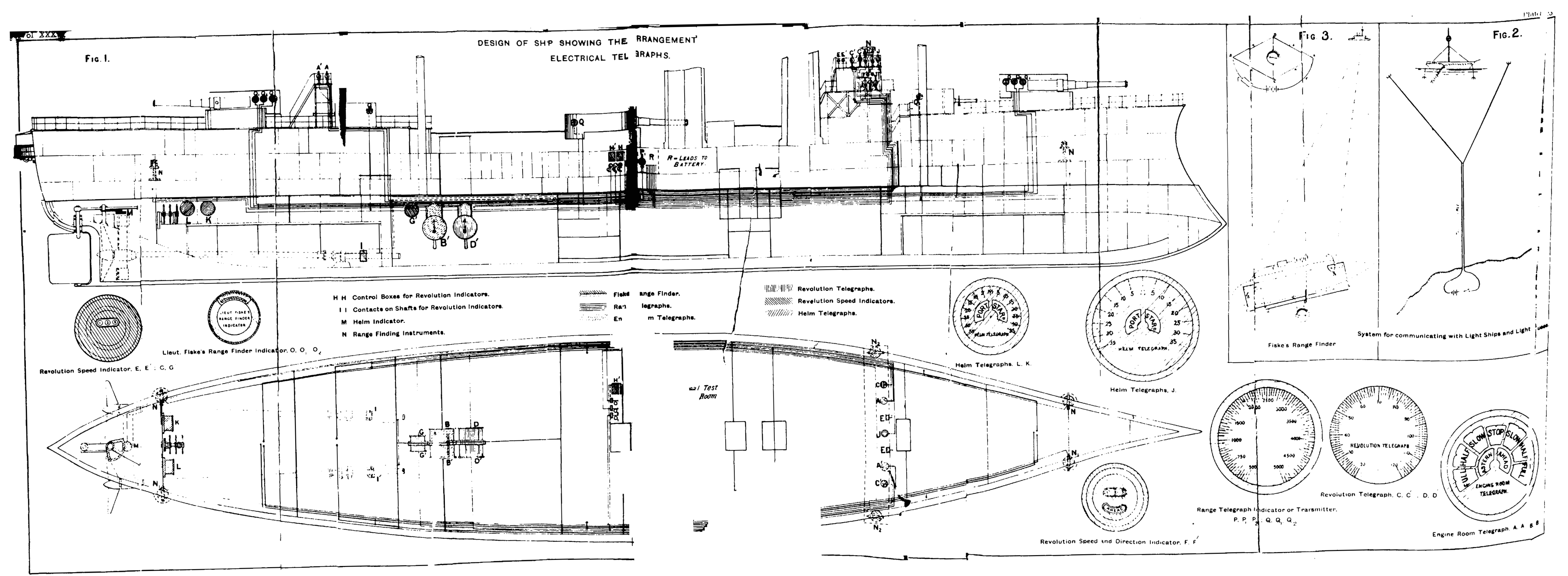




\section{Elcóric Communioationis.}

- Electricity lends itself to increasing: the convenience and rapidity. of communications to a very great extent, for signalling beyond the visual distance it is the only method, ibesides sound, and for short distances where the places between which it is desired to communicate are separated by walls or decks; or bulkheads, it is often the most : handy method : In our modern : ships : of war, for instance; when it is desired to communicate between conning towers or bridges and the engine room, we find armoured bulkheads; watertight bulkhosids, and all sorts of obstiructions in the way, so.if we wish to have one of the old fashioned telegraphs worked by rods we either: have to lead the rods in exposed positions where they areiliable to be shot away in action, or we have to make holes through watertight : bilkheads, : thns 'endangering their efficièncy, or make so 'many angles and gearings that: the telegraphs are'alinost:aseless on acconnt of the friction and, back lash in the working parts. For this prirpose then eloctric telegraphs :are peculiarly adapted; distance (within the posibible limits of a ship) and angles make no difference; and if the wires connecting the instruments are'severed by shot in action; they are easily repaired, whilst the rods of the mochanical telegraph could probably jòt bo - repairéd without dockýard : assistance. ' Different patterns of these electrical telegraphs have now been in use for some time; the difficalilies to. be overcome with regard to them are, first, the :efficiency; ander circumstances of sea service, of the batteries or other sources of electricity that work them, and, secondly, that they. should indicate acciurately at whatever speed the luandle is moved, as however caireful an Officer of: the watch may be he will naturally push the engine room telegraph over with a jerk if he finds that his ship is just going to run into something. To get over the difficulty of the batteries, nearly every known source of electricity has been tried. The current required should be large, as the larger it is the less delicatie the instruments need be ; naturally, therefore, secondary batteries have been tried, but by reason of their delicacy and the care required in their use they are not altogether a success. 'Primary batteries, as being more easily repaired or replaced, have been. more. largely used, but it is difficult to got great power from them. It is also proposed to work telegraphs with the direct current from the dynamo machine; an instrument of this description has been invented by Mr. Richards, a Constructor in the Admiralty.: It only takes half the amount of current necessary to light one lamp, and that only intermittently, whilst it is in actual motion; and as in our modern ships we have ample dynamo power; and always have steam to work it. when under way, there seems to be no objection to using the dynamo as our source of electricity; this is, howerer, quite a new departine, and we have not yet got any practical experience of its working.

The machine that is at present.most commonly. in use is the Willis's, and the latest improvement of it, the Willis and Robinson's 
telegraph. This instrument can be worked either by secondary or by primars batteries. The great point in its farour is that it can. not be thrown out of adjustment by being worked too rapidly, as the handle is not in direct connection with the electric mechanism. The fact of putting the handle orer winds up, or extends or compresses a spring, which, in its turn, drives some clockwork; this makes the contacts; and no matter how angry or excited the Officer of the watch may be, the clockwork will only cause the contacts to be made at a certain slow and deliberate pace, quite fast enough for all practical purposes, but not so fast as to incur any danger of npsetting the adjustments. Another good point is that should this instrument show the wrong indication through the handle being worked when the battery is disconnected for any purpose, or through eny other cause, it will readjust itself, simply by putting the handle hard over.

Instraments of this description are ased for engine-room telegraphs, helm telegraphs and indicators, and for distance indicators to telegraph the distance of the enemy or target from the Officer taking the range to the guns. To prevent the possibility of mistakes, it is always advisable, in any instrument of this description, to hare an answoring dial, so that jou can sce that the man at the ather end has receired the correct signal.

A large irouclad now being built at the Forges et Chantiers de la Méditerrance is quite the most perfectly fitted ship, electrically speaking, that has ever been built; she has electricity for eversthing, and we shall hare to refer to her more. than once. Among otber things she is to be fitted with a most elaborate system of telcgraphs for all purposes (sce Fig. I). Messrs. Elliott are now preparing the instraments ; they consist of engine-room telegraphs, belm telegraphs and indicators. distance indicators and telegraphs, and rerolution indicators. These last are very ingenious instruments, invented by Spratt. The fact of pressing a button on the side of the instrument clears off any former record, and starts the clockwork, which goes for fifteen seconds; on the ecrew shaft is an electrical contact that is mado four times in cach revolution, at each contact tho instrument indicates one; so that, at the completion of the fifteen seconds, the number shown is the number of revolutions the engines are making per minute.

Whilst on the subject of telegraphs, it will not be ont of place to consider the question of electric logs. A difticnlty has always been, to keep the rerolring contact watertight; this has now been got orer in Granville's log, by making the log itself one plate of the battery for working the instrament, the iron bull of the ship the other plate, and the sea itself the exciting liquid, so that insulation is not required. It only remains therofore to decide what combination of metal with iron will give us the best result. Zinc gives a bigh electromotire force, but is not constant, as the sea water acting on the zinc oxidises it and the strength fails, necessitating constant cleaning. Plumbago gires the best results altogether, as it makes a cell strong enough to work one dial, and does not oxidise at all. If it is desired to ase 
more than one indicator, the difficulty is easily got orer by making the small current from the log work a small and delicate relay, through which a powerful battery on board conld be made to work as many instruments as you like. A combination of this instrument with a revolution indicator such as I have jnst described would enable yon to read the specd at any minute by only pressing a button and waiting a few seconds until the counter had finished connting.

The telegraph for distant signalling of messages is of course now nniversal, and it is therefore very likely that in war-time men-of-war may have to use it under circumstances that will make it impossible for the proper operators to attend. This makes it necessary that a small body of seamen should be trained in the use of the instruments. For this purpose there is a school of telegraphy at Portsmouth; and ccrtain ships are supplied with instruments, so that the men may be kept efficicnt.

Another use of the telegraph that we are hearing $*$ good deal about at present is for communication with outlying lighthouses and lightships. There are two difficulties in the way: first, that of getting the wire on board the lightships that must of necessity swing to the wind or tide, or through tho surf that is sure to be continually beating on the rocks round an outlying lighthousc.

Numerons watertight swirel contacts have been tried for the lightships, they are more or less satisfactory for a time, but they con. stantly break down; and as for tho lightliunses, no shore end of cable has jet been made with a sufficiently heavy armouring to stald tho action of a heary surf on rocks for very long. A plan has, however, been patented by the Telegraph Construction and illaintenance Company, by which communication can be made to both lighthouses and lightships without the cable actually going on board them at all. The plan is this. A twin cable is led out from the shore.to within about a quarter of a mile of the lighthouse or ship, the cores are then forked out, and end in large carth plates about one-quarter of a mile apart, one on either side of the place wo want to telegraph to. Two earth plates are put overboard, one from either end of the lightship, or on either side of the lighthouse (see Fig. II). If now MIorse signals are sent along the twin cable from the shore, using an interrupted carrent produced by a clockwork sonnder, they can be distinetly heard in a telephone on board the lightsbip. This plan is now under trial, and, I am told, is likely to get over the difficulty of communication.

But the second difficulty is not so easily disposed of. At present lighthouses and lightships are sapposed to bo exempt from attack in war-time; but if we have telegraphs to them, it will be a sore temptation to use them as outlying signal stations for reporting the enemy's movements, and even if our morality is proof against the temptation, what enemy is going to gire us eredit for such correct behaviour? The result is, we should, as soon as war is declared, have either to remore them or protect them. The impossibility of protecting them is shown when I point ont that there aro orer fifty round the coasts of the British Isles that an enemy night suppose to 
be connected by telegraph, and that he would tlierefore be quite justified in destroying.

The telephone is not of much use in a man-of-war, as eren in ordinary circumstances the noise of the engines, and the noises insep. arable from having several men living together in a confined space, make it difficult to hear through; and in actinn it would of course be absolutely useless. It has also been giren up by divers, as they prefer a roice tube, but it is of great use for running temporary lines for signalling during shore operations, or for keeping up communica: tion between different parts of a mine-field, whilst laying nines for the defence of an anchorage.

Another way in which electricity helps us in signalling is by using either coloured or flashing electric lights. There is one system in which three lanterns are used, from which you can at will show either a red or white light. 'Thus if three lights are used together we can get eight combinations, and if two lights are used as well four more combinations may bo obtained. These twelre would be quite sufficient for the few important signals that are required to be carried out quickly at night, such as large alterations of course, stopping engines, or starting. The system lias also been largely extended, so as to make a complete code, by increasing the number of lanterns and using, in addition, indicator lights to point out tho chapters of the signal book to which the number shown refers. In connection with this s5stem, an Officer of the Austrian Nary has introduced an ingenious but somewhat elaborate switch, whereby the operator only has to set the number of the sign on a keyboard, turn the switch, and the proper signal is automatically shown.

Great difficulty has been found to make the flashing system work properly. There aro two ways in which tho flashes can be produced, first, by veiling the light, and, secondly, by extinguishing it; if a light is extinguished by a switch in the ordinary manner, you will notice that it takes a very long time for the carbon to cool down to blackness, and, being cold, it also takes a long time to warm up again to incandescence; the higher the candle power of the lamp, and, therefore, the thicker the carbon thread, the longer this takes. 'The result is, either the flashes have to be so slow that it is difficalt to take in the signal, or they aro all blurred together and it is impos. sible. Another difficulty is, that when the current carricd through a switch is large, as it is in the case of lamps of high candle power, each break of tho current causes a spark that in a short time burns up the switch.

'Therefore, to get over these difficulties, several attempts hare been mado to produce the flash by reiling a light that is continuonsly burning; thes have not been satisfactory, as the fact that the mechanism must be always cxposed to bad weather and to riolent alternations of heat and cold, render's a delicate instrument impossible; whilst, of course, a large and heavg instrument cannot bo placed aloft where, for distant signalling, the fashing light is principalls required.

We therefore hare to fall back again on the extinguishing system 
and try to get over the difficulties; this has been done very. fairly successfully in the following manner:-So as to allow the carbons to cool quickly, instead of having one thick fibre, we have a number of thin ones; the lamp so made is called a maltiple-fibred-lamp; and, as a still further development of the same principle, we put each of the small fibres into a small lamp of its own. This improvement gives us two advantages, first, there is better ventilation and, therefore, more rapid cooling of the fibres; and, secondly, we get rid of the risk of one loop catching over another owing to vibration of the lamp. The incandescence is more rapidly obtained by having a resistance inserted in shunt with the key, which allows i small current to be constantly runaing through the lamp, not powerfal enough to gire any light, but only sufficient to keep tho fibres at a very dull-red heat; this resistance also helps to get rid of the spark at the switch when tarning the light off; and this object is further helped by having a condenser placed so that each coating is in connection with one side of the keg. A light of this description, placed on the truck of a slip, is very useful for distant signalling, but does not, of course, hare quite the range that the search light has when thrown up into the sky, especially when there are heary clouds about that can be illurinated b5 the beam; this method, althongh slow, still remains the best for very distant work.

The next point on our programme is range-finding. Licutenant Fiskc, of the American Nary, has invented a very ingenious plan, by which clectricity can be made to assist us in fuding the range of a target or enemy's ship at sea.

Tho principle of the invention is, that wo hare two telescopes sepasated by as great a distanco as wo can conveniently obtain on board ship (see Fig. III). 'This distance, forming the base line for the calculation, should be as long as possible, so as to obtain accuracy. 'The telescopes aro inounted on horizontal arcs, which are constructed with a thin wire imbedded in insulating material, ranning round the edgo; attached to the telescope is a rubbing contact that touches this wire; the telescope pirots are joined together through a battery, and connections are made between the ends of the ares so that the two portions of cach on cither sido of the telescopes form the four arms of an electric balance, and between the arms of the balance is placed a galvanometer to indicate by its deflections when and to what extent the balance is disturbed. ${ }^{1}$ Now, if these telescopes are moved along tho liorizontal are, the resistance that tho are presents to the passage of the electric current is altered, but if the telescopes remain parallel, the resistance in both ares is altered to the same extent, and the electric balance is undisturbed, and the galranometer does not move from the zcro point, but the telescopes are only parallel when tho object to be observed is at an infinite distance. If, now, the object wears us, the telescopes begin to converge, and the nearer the object comes, the more the telescopes converge, and, therefore, the more tho balance betwcen the two resistances is disturbed, this causes a deflec-

1 The lettering on the tro diagrams in Fig. III will cnable the reader to refer the connections to the graplic diagram of the biance and so make the principle clear. 
tion of the galvanometcr proportional to the disturbance of balance. If, now, wo mark the galvanoraeter to correspond with the distances due to the different angles of convergence of the telescopes, we have at once a dircet-reading range-finder.' This description is not scientifically accurate, as it omits two errors which are so regulated as to eliminate one another, bnt it is sufficiently accurate to show the principle. This instrument is said to gire great satisfnction on board the American cruiser "Baltimore," to which it has been fitted; it has also been fitted up on board the ironclad building in France, to which I referred above, in which ship there are three pairs of instraments, viz., one pair on each brondside in small sponsons about 300 feet apart, and one pair on the fore-bridge, with a base between them of between 50 and 60 feet, for taking ranges right ahead or right asterm. These latter instruments are rather differently constructed to tho others, as, owing to the short base, they hare to bo more delicately adjusted, and they do not admit of a training of more than 5 or 6 degrees on either bow. The galvanometers for showing the distances aro placed in the electric room, a place in the centre of tho ship set apart for the testing aud management of all the electric circuits in the ship; in which room the ship's electrician and his staff would bo stationed in action. They would read off the distances from tho galvanometer and instantly telegraph them to the different guns by Willis's distance indicators.

We will now consider the application of electricity to motors. Their use for rarious purposes has increased very largely of late years, and they aro a great conveuience, owing to the ease with which the power is conreyed to them (wires being all that is required), and to the portability of the machine itself whilst working. An example of their portability is the electric drilling machine now largely nsed in the construction of iron ships.

Where power has to be distributed by the agency of steam or hydraulics, somewhat claborate fittings in the way of pipes hare to be placed, that are not only cumbersomo in themselres, but, and this is a scrious objection in a modern iron ship, they necessitate piercing the watertight bulkheads; wherens, if electricity is used, the wircs can bo led through tho bulkheads in such a mauner as to leave their watertightness still intact.

The objections to the use of elcetricity are, however, rery serions. First, there is an enormous loss of power due to the change of form in which that power is applied, i.e., commencing with steam or heat, which is our primary motire power, we change it into electricity through the medium of a dynamo, thion back into mechanical work through the medium of the motor.. The second objection is that to develop the power of a motor great speed is necessary; therefore gearing is wanted to reduco this speed to whaterer our requirements may be, and of courso the use of gearing means a further great loss of power. Thus electricity is a very extravagant way of applying force.

For working guns in ships, where wo require to apply our porser at many different points, stenn is, of course, disadvantageous, as the 
tronble of lcading steam about the ship and keeping the joints always tight, and the inconvenience attached to getting rid of the waste stcam, renders its use almost prohibitire, and another method of transmitting power becomes necessary. The means usually adopted are hydraulics, and in point of economy there is no doubt that it is far the best, for one great reason, that it can be applied direct to the work it has to do without the intervention of gearing.

Nerertheless in one or two American ships and in this new ironclad we hare already mentioned as building at the Forges et Chantiers electricity bas been adopted, I presume on account of the quality I mentioned above, viz., that it.lends itself to facilitating the transmission of power through watertight bulkheads without impairing their uscfulness, and also to the fact that the wires aro so much casier to repair if damaged in action than pipes.

This ressel is armed with four 24-cm. guns mounted en barbette, one forward, one aft, and one on each broadside, and also four pairs of 12-cm. Q.F. guns on twin mountings, the ammanition supply being between them. The larger gans are both trained and supplied with ammunition by clectricits, whilst the smaller guns have only electrical ammunition supply. For training the $24 . \mathrm{cm}$. guns, two inotors are supplied to eacli, one being spare; the motor revolves a sprocket wheel by means of a worm and wheel ; this sprocket wheel gears into an endless pitch chain which encircles tho trunk of the mounting, itself an integral part of the revolving platform. This trunk also forms the ammunition lift, and the ammunition is hoisted through it by another endless pitch chain actuated by a smaller motor. Tho ammanition hoists at tho smaller gans aro worked in a similar manner. All the motors aro therefore well down below, and are, in fact, under tho armoured deck, and in most cases, if not all, they are near steam engines, so it is difficult to see what advantage is gained, as the steam itself might have been used, but I believe the electricity is a duplication of power. 'T'ho electricity in this case is produced by two very large dynamos driren by engines that appear to be of about 40 horse power.

Motors are also used for driving launches and other small boats. Here again we bare a most extravagant form of propulsion, more extravagant eren than the motors we have just been considering for manipulating guns, as in this case we hare to make one more change, i.e., here we change our steam into mechanical work for driving the dyamo, then into electricity, which is again changed into a chemical form when charging the secondary batteries, then again into electricity, and again back to mechanical work through the motor. Each of these changes means a waste of power amounting in the aggregate to nearly half the power originally dereloped by the stcam engine.

Another disadrantage of this form of propulsion is the enormous weight of the sccondary cells; so great is this weight, that high speed is an inpossibility in an electric boat containing its own accumulators. In fact I think I shall be within the mark if I oay that no boat of this description has erer exceeded 9 miles 
an hour; the speed is reduced not only by the enormous weight the boat las to carry, bat also by the fact that, the motor rerolving at a ligh speed, the propeller has to be of short pitch; consequently the percentage slip is increased, as also is the skin friction of the propeller itself.

Against theso disadvantages we hare, when wo are dealing with vessels for pleasure purposes, absolute luxury and comfort, as there is no heat, or smell, or dirt, and little or no noise, and for war purposes wo are enabled to have a boat driven silently, and without a cliauce of sparks or smoko to betmy her advance to the enemy, therefore probably most useful for torpedo work.

It will, perhaps, be of interest if I describe a boat of each of these types recently constructed by the Electric Power and Traction Company at their works on the Thames, near Hamptou.

The pleasure vessel is a rirer yacht 55 feet long over all, and 8 fect 6 inches beam; she carries 3 toos of accumulators and machinery, consisting of 100 accumulators of the B 15 type, having an outpnt of 150 ampioro hours; these cells can be fally charged in 5 hours, und at the full speed at which the boat is driven they discharge in 7 honrs; this gives a speed of 7 or 8 miles an hour, and derelops about 5 horse power: $A$ switch close to the stecring wheel is so arranged that you can go full or half speed aheal or astern, the difference in speed being obtained by, in the case of full speed, arranging the cells 50 in series and 2 in parallel; and in the case of lialf speed, 25 in series and 4 in parallel; tho half speed is about 5 knots. 'The propeller makes between 700 and 800 revolutions a minute, its pitch being 16 inches and diameter 20 inches. All the accurnulators and the motor are either in lockers forming seats, or under the bottom boards, so that the whole of the boat is arailable for accominodation.

The boat that is presumed to be for war purposes is similar to one that was at tho Naval Fxhibition. She is a clinker built boat like a large gig 40 feet long; . she contains $2 \frac{1}{2}$ tons of accumulators and machinery, and weighs about 4 tons without warlike fittings; sho is to bo hoisted up on board a ship. Sho has 60 cells, which are ased all in series at full speed giving an output of 40 amperes for 4 hours, and a speed of 8 miles. 'Two of these boats havo been recently sold by this Company to tho Russian Government. For the purpose of comparing these boats with steam launches, it is perhaps fairest to take the 32-foot Naval Service steam cutter. In this boat with a weight of boiler and machinery (with steam up) of $1 \frac{3}{4}$ tons, we get a speed of abont 10 miles. There are, howerer, two points of advantage in tho electrical boat over the stcamboat that wo have not yet noticed : first, that in the former wo do not require to carry any extra woight, such as coal and fresh water to keep tho engines going; and, secondly, that wo can stow the weights in the electric boat te better advantage than in the steamboat, as it does not matter where the batteries aro placed, so long as they are in the boat; therefore, as thoy need not be high, wo are enabled to build a boat of deeper keel and consequently finer lines. This advantage docs not seem to have 
been made full use of yet; when it is, perhaps we may get rather better comparative results between the two modes of propulsion.

We must now pass for a few moments to the question of firing guns by elcetricity. Wo have been in the habit of using what is ter'med a "detector," that is, a galvanometer, so that we can see at any time if tho circuit is complete. An improrement on this has been recently introduced by which, instead of scoing, wo can hear if the circuit is correct by substituting a sounder for the detector. This instrument has been brought ont by Messrs. Armstrong.

Whilst on the subject of guns, I may as well also mention night sights, or a plan for illuminating the sights at night so that aining is uade much casier. As an cxample, I will take those patented by Captain Grenfell, which consist of tho very small incandescent lamps, the current for which is obtained from small primary or secondary cells. The lights themselves aro scrcened from the eye, but throw their light on inclined bars which form the sights. A switch is introduced beiween the battery and the light, with.a resis. tance in it, so that the brilliancy of the light can be regulated to suit different conditions of atmosphere. These sights will probably very much increase the accuracs of night firing.

The last subject we linve to deal with is torpedoes, not because it is least important in this connection, as it practically was brought into beiner by electricity and exists by it; there is, howerer, not much that is new to be said. I do not mean to say that as great an advance has not been made in this subject as in others; bat this adrancement is more in the nature of detail, that it would be impossible to go into in in short sketch like this, and thero is very little inrolving new principles.

As regards submarine mines, the only point we need notice is mechnnical mines, or those that carry their menns of ignition within themsolves, and therefore require no cables. They havo been brought more into prominence of late, owing to the notion laving been started of using them for what is termed "Torpedo Blockade," that is, for dropping in front of an enemy's harbour to blow his ships np. should he attempt to come out. I have often heard it said that wo never require to bottle up an enems into his ports, we want him at sea. Altbough I hope that may be true, I don't think it can bo denied that a yery short search into history will show us many cases in which we should have beun glad to have the power of worrying our enemy in this way; at any rate mines of this description would be very fair sulstitutes for cruisers watching a uarrow channel when the cruisers themselves are not obtainable.

To bo efficient they must be provided with an automatic mooring apparatus that will moor the mino at any required depth from the surface withont the necessity of previously taking soundings.

With regard to torpedoes proper, that is, mobilo charges as distinguished from stationary charges or mines, electricity is still used both as a means of steering torpcdoes and also propclling them. For propelling them, as one might expect from what wo have seen of the difficalties of clectric boats, the source of electricity cannot be con- 
tained in the torpedo itself, with any hope of attaining a high specd. We have, therefore, to fall back on the plan of haring a cable between the torpedo and the source of power, for conveying the electric current to it. The most successful torpedo of this type is the Sims-Edison, which has been going now for some years; it was fally described in Commander Batten's lecture in 1885, and since then it cannot be said to hare improred very much, but its speel and range have increased, and it is so far scrviceable that it will undoubtedly be used in war by some nations.

Attempis hare been made lately to use it from ships under way, and there is no doubt that, so far as the machinery that it is necessary to carry is concerned, it can perfectly be done. But its proper splere of usefulness is undoubtedly as an auxiliary to harbour defence. Tho difliculty with it will, I am afraid, always be the cable, for this reason. Electrical power can be obtained in two ways : we can either hare high electromotire force and suall current, or low electromotive force and large current. Lither combination will gire the same result; just as in tho use of water, a high pressure and small quantity can be mado to do the same work as a low pressure and large quantity. Now, if the electrical current running through the cable to the motor in the torpedo is very large, the cable must be large and heary; and the torpedo itself, which has to hold the cable that is to be paid out, must also bo large, so as to bo ablo to carry the weight. It is a grent advantage, therefore, to reduce the current and increase the electromotive force, bat we then come face to face with another difficulty, that if we hare high electromotive force, we must haro extra good insulation on the cable con. veying the electricity, as a leak in the insulation will be immediately fatal to the working of the motor.

Thereforo we want to hit off a mean that, whilst giving us a small current and therefore light conductor, will not unduly increase the electromotive force bejond what the insulation of a flexible and light cable is able to stand; in the end it will probabls be found that the users of this torpedo will have to rest satisfied with a cablo that will be efficient for one or two runs of the torpedo only, but will not stand more use than that. This, of course, means extra expense, a small matter in war-time.

Captain Esader. Wizrot, R.N.: Your Royal Ilighness, ladies and gentlemen, I was quite sure that we should hare a very excellent poper from licutenant Hamilton on a subject to which I liare puid some nitention, and what ne hare hoard has quite come up to my cxpectations. Ile truly says "the moro practical expericnce wo get the more wo sec that electricity for naral purposes nust be applied in such a manner that the instruments and machines used must be simple." One point also which it is desirable to bring out with regard to the internal clectric lighting of ships is this, that howercr pleasant it may be, and no doubt it is, cspecially in hot climates, there must always be the danger in action of the wires being shot awas, and the ship being thrown into darkness at a critical moment. Therefore, although wo may, pcrlaps, rels upon clectricity fo: lighting the ship below the suter-line, all the parts abore tho water-line certainly abould hare a duplicate gystem of candles or oil lamps. I could hare wished the resder of the paper had giren $u s$ a few practical illustrations of the uses to which these clectrical machines 
liad been put, and I may, perbaps, be allowed to mention one or two instances where we hare used elect ricity with rers useful effect. Ile alluded to the search lights and signalling. A few Jears ngo, when we were emplored in an operation which political circumstances compelled, riz., the blockade of the coush of Grece, in which your Royal IIighness commanded, we had a large number of ships dietributed orer a large area, and they had to be more or les 3 in communication. In the ship I commanded wo had a powerful elcctric light, and $I$ was cnabled to kecp up communication with my senior OAlcer at a distance of 20 miles by pointing the scarch light in the Bky, obserring it, and allowing it to flash forth again br means of a shutter, as now used, with an ordinars lantern for short distances. Practically we are better of for distant signalling by night than we are by dar. There is one thing, of course, to be remembered, that the clectric search light is protically useless in foggs or misty weather. The elcetric light can, howerer, be used for ditferent purposes, and I will mention one instance whero we found it exceedingly uscful. When we wero in the Red Sea in 1835 we had a powerful electric light on board. In expedition used to start off in the carly morning, and had to be supplied with water. At that time erery drop of water had to be distillerl in steamers and anllected in tanks. It was then put into skins and carried by camcls. The expeditions used to start of early in the morning, and it was necessary that the shins should be filled during tho night. So we arrsnged a series of lights on shore, composed of small incandescent lamps, which were rorkel from the ships' dynamos, through a cuble laicl to the shore. By thet means the whole of the tanks were lit up, and the procecdings were carried on with great expedition and efficiency. The nest thing ras to place the skins on the camcls' backs. The camels were brought to within a few hundred yards of where thid was going on, and were made to lie down. There nere a large number of them waiting to be louded. The next thing was that there should bo light in order to earry this into effect. I then utilized the scarch light, which was turned on the camels with a direrging lens, which cnabled the rays to epread orer a considersble distanee, and reduced the brilliancy of the light. It was a curious thing to seo tho effect on the animals. It first we thought they would start up in fright and bo off, but the only thing was that erers camel turned its head to where the light came from. It 4 or 5 o'clock in the morning, being all loaded, they marched off. That is a practical illustration of what can be done with the electric light other than for the purposes to which the lecturer lias referred. As regards the range-finder described by the lecturer, I think it hardly applicable to a ship of war at sea, under the rarying conditions of action. In the first place two obscrrers are required : they must be at different ende of the ship, and in communication with each other. Telephones will not answer when there are guns going off; I think we want something simpler than that, by which the distance can be ascertained by a single person and communicated to the guns. Certainly wo hare had a rery instructire lecture on many inferesting subjects.

Admiral CoLOYB : I am quite incapable, jour Rojal Highness and gentlemen, of discussing the paper, but when we come here it is a sort of duty that derolres upon us to endesrour to start a discussion. That has been already well started, but there seems a little hesitancy in following it up: therefore, I rise to congratu. lete my old shipmate on the lecture, which I hare most thoroughly enjoged. I only wish that I lnew something more about the subject, so that $f$ could further enter into it. But I hare a little sensation of fecling, after hearing the lecture, thist $I$ am rather glad, upon the whole, that I am out of it, because the thing is eridently getting serious, and what one feels about it is that, possible, if warfare is going to fade off into electricity, it mas be a good thing. The only part I am at all capable of appreciating is that part which referred to sigalling, and I must say I am pleased to see that ther is a possibility of at last getting moderately rapid flashes from a high point in the ship. That apparatus aeems to answer roxy well, but not perfectly, because am sure, if flashing signals are to be perfect, as they ought to be, something still more rapid than that has to be arranged. I have been much etruck watehing flashing signals in the Army. I beliero that they are further adranced than we are in that part of the acience-that their signalling is more correct and quicker than ourz. 'Thes bare the adrantage in the Areny of haring 
no other s5atem competing, and some of our competing systems undoubtedly interfere with the flashing eystem by restricting practice. It is evident that we are going on in the right track, and that results will be ultimately obtained which will bo satisfactors to ererybody. I beg to congratulate the lecturer heartily on his paper.

Admiral Loxa: Your Rogal Highness, ladies and gentlemen. Though I am by no means competent to criticize tho adnirable lecture we hare heard, I do not like to remain kilent, eccing that Lieutennnt IIamilton has taken so much pains, and has got so many beautiful instruments here to instruct us. One lesson we must all leurn from the progress of electricity in the Nars, is the adrantago of steadr, persistent application to one object. It certainly is most wonderful to me to sce the progressthat has been made in the practical application of electricits to naral things since I first went through the torpedo course in the gear 1869. Hatters were then in a very different stute to what thes are now, and I think we cannot but admire the pertinacity, the ability and zeal, with which Offecrs hare stuck to it sinee then, and lare now brought nbout a state of affairs in which, I belierc, we are sccond to no nation in Furope. 'There are only one or two points upon which I might male a remark as to commurication with lightships. It may not be generally bnown, that so long ago as 1587, there was a lightship, the "Sunk," in communication with the land by a cable, which passed up through the mooring swircl centre, which was made hollow; it ras found rery satisfactory. During the manocurres $I$ was in the Downs: we used to reccive telegrams from this lightship, telling us whether ans enems was in sight, and there was no failure at any time. With regard to the thrce-light signal system, I should like rery much to ask Iieutennut Hamilton whether we hare that system in use in any ship in the Nary. I think there is a system called the Conz, and also that of Kaselowshi, but whether it las been tried in our Serrice I am not aware. Also with reqard to the sccondary cells: I should like to ask whether the motion of the boat at sea is found to injure their permanenc5, whether thes are found to wear out more rapidly when used for that purpoze than when used on shore. There is no doubt an electrically-propelled boat is a most admirable thing for the use of torpedocs. It mas be remembered, perhaps, that on one occasion an clectrically-propelled bont went across the Channel, and its progress พas so silent that they actually cauglit a eca-gull floating on the water. That is certainly a point of great importance in torpedo warfare. In Yortsmouth Harbour it was quite curious to see how silently the electrically-propelled bont rusbed along. The want of specd, I think, is no defect for that purpose, because any boat or ressel going at high speed causes sucl a disturbance that it becomes at onco conspicuous. 'There is onc application that, perliaps, might be made of the motor-I do not know whether it erer lins been donc, but it struck me it might be a ueful way of driving fans for rentilation in out of the way places. Our ships now are full of holes and cormers which need rentilation rery much sometimes, and I think it possible that the application of electricity might be found to be useful. I do not know that there is anything clse which I can say with adrantage on this. paper. I think Licutcnant IIamilton, as we bnew ho would do, has trested the oubject very fully and very ably, and I conpratulate him very much.

Commander MIERrios, R.P.: Your Koyal Higlness and gentlemen, witl reference to 80 mo remarls which fell from Admiral Colomb about the Nary being: behind the Army as regards the rapidity of signalling, I should like to drap: attention to the fact that the conditions of our signalling are entirely different from thoee of the military. We do not spell out long meseages rord by rord, is is done by the sister Serrice. We liare a code, and it is quite possible for us to do cficiently all our signalling work much slower than is necessary for the land Serrice. Our distance signals arc generally signals referring to our codes, and can be made olowly, carefully, and taken in with certainty. We do not allempt to spell out long me*sages in which rupidity is of rers great importance. Having hai eomething to do with the preparation of the clectric flashing-signal light apparatus which Ijicutenant Hamilton has shown you, I may state that a great many, other sfstcms were eliminated before that was brought out. Our distant night signalling refere to distances of 15 or 20 miles. The Army night limelight signal apparatus, which I think Admiral Colomb was referring to os being so 
rapid, is only used at a dietance of 2 or 3 miles. Of course the military day system of the lieliograph is rery rapid, and is capable of being used at lone distances. For our dajtime long-diatance signals wo hare to depend upon inferior uncthods, because we cannot get the steadiness of plutform necessary for the heliograph; but for night long-distance signalling tho comparative slowness is really no great objection to our system, because we aro generally using a code and not Epclling out words.

II.K.H. the Desc or EDIserdall : I think it is the duty of the Chairman to bring a discussion on a paper to an end. If tosk is made a rery casy one by the admirable pnper which we liare had before us, and which has left rers little open to criticism, as lias been clearly shokn by the rery small number of competitors who laso come in to offer suggestions of their own. I cain onls point out onc little omission in the lecturer's paper, which is, that whilst he mentioned the work which is being done at Yortsmouth with regard to theec matters, he orerlooked the fset that there is a port rather further west from which $I$ liailed yesterday. The instruments which sou hare seen are most interesting, and they are of course immensely in adrance of anthing we had before. I cannot at the ame time help fecling that if we arc to trust entirely to clectrical communication, and to evergthing being worked by electricity in a ship in time of action, we shall stand at a great deal of rist. Of course, there is the great difficulty of getting from one part of a ship to nnother, and communicating, as the lecturer has pointed out, through these bulkheads and armoured decks, and so on; but it is to be hoped means will be found that we shall not lare to trust entirely to one single wire, which after all mas go wrong. Admiral Long expresecd the liope that there would be otber applications of clectricity, for instance, to the purposes of rentilation. I may wention to him that I saw most aclmiruble little electric fans last jear in the Emperor of Russia's. new jocht then at Fulmouth, which were fitted in all the lower parts of the ship, which liad no scuttles. These fans when worked gare a most beautiful current of sir; but thes liad the great drawback of being rather noiss, and I expect a good mans people who manted to slecp would feel inclined to turn off the fans and do without the fresh air. I do not think I am sufliciently an crpert to discuss anj of the details into which the lecturer has entered. I will therefore conclude this discussion by tendering him our warmest thanks for his most interesting and instructire lecture.

Licut cuant F. T. Ifascturox: The only point, your Royal Highness, in the discussion which I think requires a word from me is that raised by Captain FirdleyWilmot. I do not think I made it quite clear as to the range-finder for rightabcad mork. This ship to which I hare becn alluding has range-finders for that purpose. They hare a 50-fect base line across the bridge, and the instrument, instcad of having a wire running round the are, has it wound on a coil, so that a rery slight motion of the telescope will gire a large motion of the rubbing contact on the wire. With the instrument 80 modified jou ean get the range with accuracy up to $4^{\circ}$ or $5^{\circ}$ of training on cach bow. With regard to the erplanation not being mathematically correct, I think I confessed that in the lecture. The matheniatical crrors in my explanation are tro in number, which are made to eliminate one another by the adjustment of a resistance in the galranometer itself.

Captain Eardex. Wirsior: I did not mean jour explanation: I meant the instrument was not mathematically correct.

Licutenant IIsurmos: I think you will find that it is made so with this correction. Witl regard to the three lights which Admiral Long spoke of, that sfstem has becn in use in the Aagship in the Channel for some three or four Jears. "They rigged it up themselves in tho "Northumberland" originally, and it was afterwards uscd in the Vediterrancun. Thes found it, I beliere, most uscful for alterations of course at night and that sort of thing. With regard to the motion of the boat injuring tho secondary cells, there is no doubt it does. It must shorten their lires to a ccrtain extent, but there is rery little experience of them in any places where the boats knock about at all. The principal place where electric boats hare been used up to now, is on the Thames as pleasuro boats, and there I do not know that they find rery much dificulty. With regard to the fans Admiral Long spoke of, in addition to those mentioned by your Royal Highnese, they liare one on board 
the "Rogal Sorcrcign," fitled up as an experiment by a firm of the name of Blackmau and Co. I regret haring omitted to mention the Jelegraph School at Deronnort.

Field.Yarshal Sir F. Lrstogx d. Srmxoss, G.C.B., G.C.M.G. : We ore a debt of thanks to His Roral IIighness for coming to preside at this mecting, where we hare heard such an excecdingly interesting lecture delirered by Licutenant IIamilton. Tho remarks of Iis Rojal IIjghness are quito sufficient to show that lie highly appreciates the ralue of electricity as applied in ships-of-par and to war purpoes. Huring serred in the Mediterranean when His Rojal Highness commanded the flect on that station, it was a source of great gratification to me alwass to sce that fect maintained in the highest order and in the most perfect condition, and to know that erery encouragement was giren to Oflicers to derelop any project that might be beneficial to the Serrice of which he is so great an ornament. I ask Jou to offer jour sincere thanks to His Royal Highness for presiding on this occasion.

Admiral Sir E. Farsiawe: I beg leare to sccond that.

(The resolution was carricd by acclamation.)

II.R.II. the DCEE of EDIxponaI : I beg to thank sou and to assure you it has ecen a great pleasure to me to be present. 